\title{
Coastal measurements of short-lived reactive iodocarbons and bromocarbons at Roscoff, Brittany during the RHaMBLe campaign
}

\author{
C. E. Jones ${ }^{1}$, K. E. Hornsby ${ }^{1}$, R. M. Dunk ${ }^{1}$, R. J. Leigh ${ }^{2, *}$, and L. J. Carpenter ${ }^{1}$ \\ ${ }^{1}$ Department of Chemistry, University of York, Heslington, York, YO10 5DD, UK \\ ${ }^{2}$ Department of Physics and Astronomy, University of Leicester, Leicester, LE1 7RH, UK \\ *now at: Crichton Carbon Centre, Crichton University Campus, Dumfries, DG1 4ZL, UK
}

Received: 17 July 2009 - Published in Atmos. Chem. Phys. Discuss.: 14 August 2009

Revised: 20 October 2009 - Accepted: 5 November 2009 - Published: 17 November 2009

\begin{abstract}
Atmospheric concentrations of the volatile reactive iodocarbons $\mathrm{C}_{2} \mathrm{H}_{5} \mathrm{I}, 1-\mathrm{C}_{3} \mathrm{H}_{7} \mathrm{I}, 2-\mathrm{C}_{3} \mathrm{H}_{7} \mathrm{I}, \mathrm{CH}_{2} \mathrm{ICl}$, $\mathrm{CH}_{2} \mathrm{IBr}, \mathrm{CH}_{2} \mathrm{I}_{2}$ and bromocarbons $\mathrm{CH}_{2} \mathrm{Br}_{2}$ and $\mathrm{CHBr}_{3}$ were determined by GC/MS analysis of marine boundary layer air at Roscoff, Brittany on the northwest coast of France during September 2006. Comparison with other coastal studies suggests that emissions of these trace gases are strongly influenced by site topography, seaweed populations and distribution, as well as wind speed and direction and tide height. Concentrations of the very short-lived dihalomethanes $\mathrm{CH}_{2} \mathrm{IBr}$ and $\mathrm{CH}_{2} \mathrm{I}_{2}$ in particular showed evidence of tidal dependence, with higher concentrations observed at low tide during maximum exposure of seaweed beds. We also present a limited number of halocarbon measurements in surface seawater and estimate sea-air fluxes based on these and simultaneous air measurements. $\mathrm{CH}_{2} \mathrm{Br}_{2}$ and $\mathrm{CHBr}_{3}$ were strongly correlated both in air and in seawater, with $\mathrm{CH}_{2} \mathrm{Br}_{2} / \mathrm{CHBr}_{3}$ ratios of 0.19 in air and 0.06 in water. The combined midday $\mathrm{I}$ atom flux from the photolabile diahlomethanes $\mathrm{CH}_{2} \mathrm{I}_{2}, \mathrm{CH}_{2} \mathrm{IBr}$ and $\mathrm{CH}_{2} \mathrm{ICl}$ of $\sim 5 \times 10^{3}$ molecules $\mathrm{cm}^{-3} \mathrm{~s}^{-1}$ is several orders of magnitude lower than the estimated I atom flux from $\mathrm{I}_{2}$ based on coinciding measurements at the same site, which indicates that at Roscoff the major I atom precursor was $\mathrm{I}_{2}$ rather than reactive iodocarbons.
\end{abstract}

\section{Introduction}

Emission of iodine- and bromine-containing trace organic compounds into the atmosphere affects the chemical balance of both the troposphere and the stratosphere and has

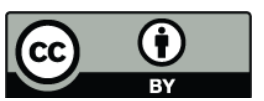

Correspondence to: C. E. Jones (cej103@york.ac.uk) implications for climate. The breakdown of photolabile organic iodine compounds (iodocarbons) to release I atoms and subsequent formation of $\mathrm{IO}$ can initiate catalytic ozone depletion cycles and modify $\mathrm{NO} / \mathrm{NO}_{2}$ and $\mathrm{OH} / \mathrm{HO}_{2}$ cycles with resulting effects on lifetimes of other climatically important trace gases (Vogt et al., 1999; Carpenter, 2003; Bloss et al., 2005; Read et al., 2008) within the marine boundary layer (MBL). In contrast to the iodocarbons which are broken down within the troposphere, it has been suggested that a fraction of the relatively longer lived bromocarbons (e.g. $\mathrm{CH}_{2} \mathrm{Br}_{2}$ and $\mathrm{CHBr}_{3}$ ) can be transported to the lower stratosphere, and potentially contribute $\sim 20-60 \%$ of stratospheric bromine (Sturges et al., 2000; Pfeilsticker et al., 2000; Nielsen and Douglass, 2001).

Short-lived volatile halogenated organic compounds (VHOCs) are produced by marine algae, and although the exact purpose of their production is not fully understood, possible explanations include release of halocarbons by means of a chemical defence mechanism against grazing herbivores (Wever et al., 1991) and as by-products of reactions to scavenge oxidants such as $\mathrm{H}_{2} \mathrm{O}_{2}, \mathrm{OH}$ and $\mathrm{O}_{3}$ which may cause damage to the plant (Pedersen et al., 1996). $\mathrm{H}_{2} \mathrm{O}_{2}$ is produced by normal metabolic activity within the plants cells, however when macroalgae (seaweeds) are subjected to oxidative stress, additional $\mathrm{H}_{2} \mathrm{O}_{2}$ is released as part of a defence mechanism, and can reach levels that exceed the plants cellular scavenging capacity (Theiler et al., 1978; Pedersen et al., 1996; Palmer et al., 2005). Iodide and bromide ions are accumulated within macroalgae at concentrations of up to 30000 times their seawater concentrations (Küpper et al., 1998) and are incorporated into an $\mathrm{H}_{2} \mathrm{O}_{2}$ removal mechanism, catalysed by haloperoxidase enzymes, to produce hypohalous acids ( $\mathrm{HOI}$ and $\mathrm{HOBr}$ ), which are thought to subsequently react to form polyhalomethanes such as $\mathrm{CH}_{2} \mathrm{I}_{2}$ and $\mathrm{CHBr}_{3}$ (Wever et al., 1991). There is evidence for increased halocarbon production from inter-tidal macroalgae during low tide when the

Published by Copernicus Publications on behalf of the European Geosciences Union. 
plant is exposed and subjected to oxidative stress (Pedersen et al., 1996). The mono-iodinated compounds are believed to be produced by a different pathway involving methyl transferase enzymes (Wuosmaa and Hager, 1990).

The precusors for iodine atoms in coastal areas were initially proposed to be iodine-containing short-lived VHOC (Carpenter et al., 1999). However, more recent studies show that biogenic emission of $I_{2}$ by macroalgae is one of the most important processes responsible for the observed iodine levels in the coastal MBL (McFiggans et al., 2004; Saiz-Lopez and Plane, 2004; Pirjola et al., 2005). The source of $\mathrm{I}_{2}$ appears to be the reaction of atmospheric $\mathrm{O}_{3}$ with the iodide accumulated in macroalgae (e.g. Laminaria digitata) when the plants are exposed to ambient air at low tide, leading to the direct release of $I_{2}$ into the atmosphere (Palmer et al., 2005; Küpper et al., 2008). Mixing ratios of up to 93 ppt $I_{2}$ have been detected at Mace Head on the west coast of Ireland (Saiz-Lopez et al., 2006), but in contrast, no $\mathrm{I}_{2}$ was observed above the instrument detection limit ( $\sim 20 \mathrm{ppt})$ during a study at a French coastal site in Brittany (Peters et al., 2005). In addition, very high concentrations of reactive iodocarbons were measured during the Brittany study, such that it was proposed that the observed levels of IO could be sustained by photolysis of the iodine-containing VHOCs alone (Peters et al., 2005).

Both macroalgae and microalgae (phytoplankton) are thought to initiate release of volatile iodo- and bromocarbons, and consequently the marine environment provides the major source of these trace gases to the atmosphere. Production from macroalgae provides a relatively large localized source to the coastal MBL, and although per unit biomass production from microalgae is considerably less (Tokarczyk and Moore, 1994), microalgae have the potential to provide an ocean-wide source and so may be significant in terms of global scale emissions.

There have been a number of attempts to "scale up" halocarbon measurements from a limited number of locations to the global scale in order to calculate global emission estimates for these gases, and hence assess their importance as a halogen source to the atmosphere (e.g. Moore and Groszko, 1999; Quack and Wallace, 2003; Butler et al., 2007). All of these studies have noted that there is considerable uncertainty associated with these estimates, not least as a result of the very limited spatial and temporal range in which concentrations of very short lived halocarbons have been reported, particularly in coastal and coastally influenced waters (Butler et al., 2007). Consequently, increasing the temporal and spatial resolution of halocarbon measurements is essential, and in this study we contribute to this by reporting the concentrations of a number of short-lived VHOC, including the very short-lived dihalomethanes $\mathrm{CH}_{2} \mathrm{ICl}, \mathrm{CH}_{2} \mathrm{IBr}$ and $\mathrm{CH}_{2} \mathrm{I}_{2}$, as well as $\mathrm{CH}_{2} \mathrm{Br}_{2}$ and $\mathrm{CHBr}_{3}$, in ambient air at a coastal site in Roscoff, Brittany during the Reactive Halogens in the Marine Boundary Layer experiment (RHaMBLe) campaign in September 2006.

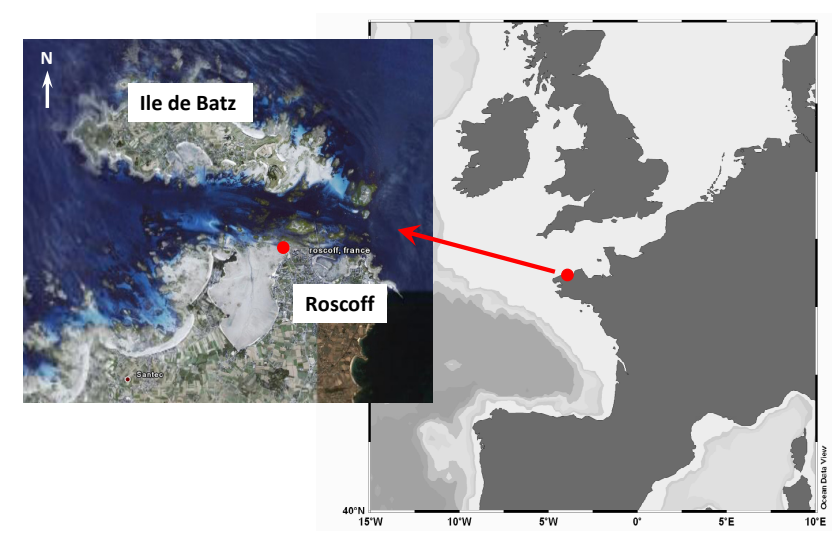

Fig. 1. The measurement site for the RHaMBLe experiment at Roscoff on the coast of Brittany is indicated by the red dot on both maps. The inset shows the local topography, with seaweed beds to the south east exposed at low tide and the island Ile de Batz to the north.

\section{Methods}

The measurement site on the Atlantic coast of Roscoff in Brittany, France $\left(48.72^{\circ} \mathrm{N}, 3.97^{\circ} \mathrm{W}\right)$ was chosen in light of the recent work of Peters et al. (2005) which had found elevated levels of halocarbons and halogen oxides further along the Breton coast at Lilia, a coastline with a high inter-tidal range which results in exposure of a vast area of seaweed beds at low tide. Figure 1 shows the location of the Roscoff site which is surrounded by seaweed beds to the north (between Roscoff and the island Ile be Batz), east (towards the open ocean) and south east, which all become exposed at low tide to some extent, and the town to the south.

\subsection{Analysis of halocarbons in air}

Ambient air measurements were made continuously between the 3 and 27 September 2006, with short breaks in sampling for calibrations and instrument maintenance. Halocarbon concentrations in ambient air were determined using a fully automated Perkin Elmer Turbomatrix gas chromatographymass spectrometer $(\mathrm{GC} / \mathrm{MS})$ with $60 \mathrm{~m} \times 0.32 \mathrm{~mm}$ internal diameter DB5 capillary column and detection by electron impact ionisation quadrupole mass spectrometry. Volatile gases were pre-concentrated from $3 \mathrm{~L}$ air samples $(100 \mathrm{ml} / \mathrm{min}$ for $30 \mathrm{~min}$ ) prior to analysis using a Perkin Elmer Turbomatrix thermal desorption unit (TD) with a chemical adsorbent trap (Air Monitoring Trap with carbon-based adsorbent, Perkin Elmer). The trap was held at between -30 and $-10^{\circ} \mathrm{C}$ during sampling, then rapidly heated to $300^{\circ} \mathrm{C}$ to facilitate desorption to the GC/MS. The sample inlet was located $\sim 20 \mathrm{~m}$ behind the high tide mark, at a height of $\sim 5 \mathrm{~m}$, and air was pumped through a $60 \mathrm{~m}$ Teflon PFA manifold at a rate of $\sim 30 \mathrm{~L} / \mathrm{min}$. A clean metal bellows pump (Senior Aerospace Limited) diverted $100 \mathrm{ml} / \mathrm{min}$ from the manifold to the online 
Table 1. The mean and range (10th and 90th percentiles) of halocarbon mixing ratios (all ppt) measured in air during the RHaMBLe campaign, and compared to mixing ratios observed in previous studies.

\begin{tabular}{lccccc}
\hline & $\begin{array}{c}\text { Roscoff } \\
\text { (RHaMBLe, } \\
\text { this work) }\end{array}$ & $\begin{array}{c}\text { Lilia } \\
\text { (Peters et al., } \\
2005)\end{array}$ & $\begin{array}{c}\text { Mace Head } \\
\text { (Carpenter et al., } \\
1999^{*} \text { and 2003** }\end{array}$ & $\begin{array}{c}\text { Dagebüll } \\
\text { (Peters et al., } \\
\text { 2005) }\end{array}$ & $\begin{array}{c}\text { Spitzbergen } \\
\text { (Schall and Heumann } \\
1993)\end{array}$ \\
\hline & Range (mean in brackets) & Range & Range (mean in brackets) & Range & Range \\
\hline $\mathrm{CH}_{2} \mathrm{ICl}$ & $0.03-0.17(0.10)$ & $0.35-12.4$ & $<0.02-0.21(0.11)^{*}$ & $0.1-3.0$ & $<0.004-0.18$ \\
$\mathrm{CH}_{2} \mathrm{I}_{2}$ & $0.01-0.07(0.03)$ & $0.11-19.8$ & $0.02-0.36(0.05)^{*}$ & $0.3-3.1$ & $<0.08-1.02$ \\
$\mathrm{CH}_{2} \mathrm{IBr}$ & $0.01-0.13(0.06)$ & $0.55-9.90$ & $<0.02-0.32(0.08)^{*}$ & $0.04-0.2$ & - \\
$\mathrm{C}_{2} \mathrm{H}_{5} \mathrm{I}$ & $0.21-0.82(0.46)$ & $2.22-96.9$ & $0.02-0.21(0.06)^{*}$ & $0.3-0.7$ & $<0.02-2.28$ \\
$1-\mathrm{C}_{3} \mathrm{H}_{7} \mathrm{I}$ & $0.08-0.36(0.18)$ & $0.35-34.8$ & - & $0.01-1.0$ & - \\
$2-\mathrm{C}_{3} \mathrm{H}_{7} \mathrm{I}$ & $0.29-0.74(0.47)$ & $0.20-9.10$ & - & $0.1-0.3$ & - \\
$\mathrm{CH}_{3} \mathrm{I}$ & - & $7.6-1830$ & $0.12-1.47(0.43)^{*}$ & $4.7-23.5$ & $<0.004-2.12$ \\
\hline $\mathrm{CH}_{2} \mathrm{Br}_{2}$ & $0.28-1.36(0.75)$ & $2.36-262$ & $0.28-3.39(1.44)^{* *}$ & $0.4-2.0$ & - \\
$\mathrm{CHBr}_{3}$ & $0.56-5.35(2.73)$ & $10.5-393$ & $1.9-16.3(6.27)^{*}$ & $1.1-11.2$ & - \\
\hline
\end{tabular}

* denotes Mace Head data from Carpenter et al. (1999)

** corresponds to data from Carpenter et al. (2003)

air trapping system, and air was continuously sampled every $\sim 90$ min, 24 h per day.

Iodinated species targeted for analysis were $\mathrm{C}_{2} \mathrm{H}_{5} \mathrm{I}$, 1$\mathrm{C}_{3} \mathrm{H}_{7} \mathrm{I}, 2-\mathrm{C}_{3} \mathrm{H}_{7} \mathrm{I}, \mathrm{CH}_{2} \mathrm{ICl}, \mathrm{CH}_{2} \mathrm{IBr}$ and $\mathrm{CH}_{2} \mathrm{I}_{2}$, and the brominated gases monitored were $\mathrm{CH}_{2} \mathrm{Br}_{2}$ and $\mathrm{CHBr}_{3}$. Calibrations were achieved using a permeation oven based dynamic dilution technique (described in detail in Wevill and Carpenter, 2004), in addition to daily analysis of an in-house prepared iodocarbon and bromocarbon gas standard (ppt levels in CP grade nitrogen) to account for any day-to-day drift in instrument sensitivity.

\subsection{Analysis of halocarbons in seawater}

On two days during the campaign an identical Perkin Elmer GC/MS equipped with purge and trap facility was used to analyse surface seawater samples for halocarbon concentrations, alongside the continuous air measurements. $40 \mathrm{ml}$ water samples in air-tight gas syringes were collected from several locations between the site at Roscoff and Ile de Batz. The water samples were filtered through Minisart $0.45 \mu \mathrm{m}$ cellulose filters and stored in the dark at $3^{\circ} \mathrm{C}$ for a maximum of $6 \mathrm{~h}$ prior to analysis. Storage tests carried out during previous campaigns have shown that storing water samples in this way for a period of several hours results in a variation in the measured concentrations of between 4-19\%. Seawater samples were sparged for $50 \mathrm{~min}$ at $50^{\circ} \mathrm{C}$ with zero grade nitrogen gas (BOC) at a flow rate of $50 \mathrm{ml} / \mathrm{min}$ in order to extract the volatile components into the gas phase prior to pre-concentration using a Perkin Elmer Turbomatrix thermal desorption unit, identical to the system used for analysis of halocarbons in air. Sparging efficiencies for all halocarbons were $>95 \%$.

\section{Results}

The average and range of halocarbon mixing ratios measured in ambient air during the RHaMBLe campaign at Roscoff are given in Table 1. The atmospheric concentrations of these gases are constrained by a number of different biological and physical conditions and processes, and our observations are discussed in light of each of these controlling factors below.

\subsection{Factors influencing halocarbon concentrations in ambient air}

\subsubsection{Sources}

While the dominant source of halocarbons in coastal air is thought to be macroalgae, emission rates vary considerably between species, and the Laminaria plants (e.g. Laminaria digitata, Laminaria saccharina, Laminaria hyperborea) in particular accumulate more iodine than other species, and are believed to be among the most prolific halocarbon-producing macroalgae (Küpper et al., 1998; Laturnus 1996; Pedersen et al., 1996; Carpenter et al., 2000). The distribution of seaweed species at Roscoff is relatively non-uniform and the intertidal zone is mainly dominated by Fucus (which has been shown to produce significantly reduced levels of volatile halocarbons compared to the Laminariales order, Carpenter et al., 2000). However, there is a small amount of Laminaria digitata, Laminaria saccharina and Laminaria ochroleuca in the channel between the site and Ile de Batz, and large Laminaria (mainly hyperborea) beds to the north of Ile de Batz (McFiggans et al., 2009). Our observations at Roscoff are consistent with significant iodocarbon production from Laminaria, however, as a consequence of the non-uniform distribution of seaweed populations at this site, the influence of 
Table 2. The low tide to high tide ratio of each species. Superscripts $\mathrm{a}, \mathrm{b}$ and ${ }^{\mathrm{c}}$ correspond to the difference between low tide and high tide concentrations being significant at the 99.9, 99.0 and $95.0 \%$ confidence levels respectively; ${ }^{d}$ indicates no significant tidal dependence, or a difference with less than $95 \%$ confidence.

\begin{tabular}{lccccc}
\hline Date & All data & $\begin{array}{c}3-5 \\
\text { Sept } \\
\text { Air mass }\end{array}$ & $\begin{array}{c}5-14 \\
\text { Sept } \\
\text { B }\end{array}$ & $\begin{array}{c}14-21 \\
\text { Sept } \\
\text { C }\end{array}$ & $\begin{array}{c}21-27 \\
\text { Sept } \\
\text { D }\end{array}$ \\
\hline $\mathrm{CH}_{2} \mathrm{ICl}$ & $0.79^{\mathrm{c}}$ & $0.79^{\mathrm{d}}$ & $0.77^{\mathrm{c}}$ & $0.97^{\mathrm{d}}$ & $0.71^{\mathrm{d}}$ \\
$\mathrm{CH}_{2} \mathrm{I}_{2}$ & $2.17^{\mathrm{a}}$ & $1.96^{\mathrm{d}}$ & $2.36^{\mathrm{b}}$ & $3.70^{\mathrm{b}}$ & $1.94^{\mathrm{d}}$ \\
$\mathrm{CH}_{2} \mathrm{IBr}$ & $2.31^{\mathrm{a}}$ & $1.32^{\mathrm{d}}$ & $2.55^{\mathrm{a}}$ & $2.11^{\mathrm{b}}$ & $2.60^{\mathrm{c}}$ \\
$\mathrm{C}_{2} \mathrm{H}_{5} \mathrm{I}$ & $0.97^{\mathrm{d}}$ & - & $0.98^{\mathrm{d}}$ & $1.03^{\mathrm{d}}$ & $1.11^{\mathrm{d}}$ \\
$1-\mathrm{C}_{3} \mathrm{H}_{7} \mathrm{I}$ & $0.99^{\mathrm{d}}$ & - & $1.12^{\mathrm{d}}$ & $1.00^{\mathrm{d}}$ & $1.01^{\mathrm{d}}$ \\
$2-\mathrm{C}_{3} \mathrm{H}_{7} \mathrm{I}$ & $0.79^{\mathrm{d}}$ & - & $0.83^{\mathrm{d}}$ & - & - \\
$\mathrm{CH}_{2} \mathrm{Br}_{2}$ & $1.07^{\mathrm{d}}$ & $1.02^{\mathrm{d}}$ & $1.15^{\mathrm{d}}$ & $1.01^{\mathrm{d}}$ & $1.04^{\mathrm{d}}$ \\
$\mathrm{CHBr}_{3}$ & $1.10^{\mathrm{d}}$ & $0.95^{\mathrm{d}}$ & $1.19^{\mathrm{d}}$ & $1.01^{\mathrm{d}}$ & $1.05^{\mathrm{d}}$ \\
\hline
\end{tabular}

the seaweed speciation and distribution upon the measured iodocarbon concentrations must be considered in conjunction with physical factors such as the wind speed, wind direction, tide height and topography, and each of these factors are discussed in the following sections.

\subsubsection{Tide height}

Since the tide height determines the extent of seaweed exposure, the concentrations of halocarbons in air might be expected to exhibit a certain amount of tidal dependence. Table 2 shows the ratios of mean low tide to mean high tide halocarbon concentrations. For these purposes low tide concentrations were taken to be those measured while the tide height was $<4.25 \mathrm{~m}$ and high tide concentrations are the concentrations observed while the tide height was $>6 \mathrm{~m}$. A statistical $\mathrm{t}$-test was carried out on the high tide and low tide data sub-sets for each halocarbon to determine whether there were significant differences in their concentrations during the two periods (see Table 2). Our measurements suggest that the relationship between tide height and the instantaneous ambient air halocarbon concentration is dependent to some extent upon the atmospheric lifetime of the gas (see Table 3), since the only halocarbons which showed statistically significant elevated concentrations during periods of low tide relative to high tide were those with the shortest tropospheric lifetimes, i.e. $\mathrm{CH}_{2} \mathrm{I}_{2}$ and $\mathrm{CH}_{2} \mathrm{IBr}$. This implies that regional emissions of halocarbons with longer atmospheric lifetimes $\left(\mathrm{C}_{2} \mathrm{H}_{5} \mathrm{I}, 1-\right.$ $\mathrm{C}_{3} \mathrm{H}_{7} \mathrm{I}, 2-\mathrm{C}_{3} \mathrm{H}_{7} \mathrm{I}, \mathrm{CH}_{2} \mathrm{Br}_{2}$ and $\mathrm{CHBr}_{3}$ ) result in more extensively mixed atmospheric concentrations, and as such variations in local emissions over the course of a few hours have less impact on the background levels of these gases. Differences in the level of tide-dependence between halocarbons could also be the result of different production mechanisms, however it is known that all the measured halocarbons have strong macroalgal sources (Carpenter et al., 2000).
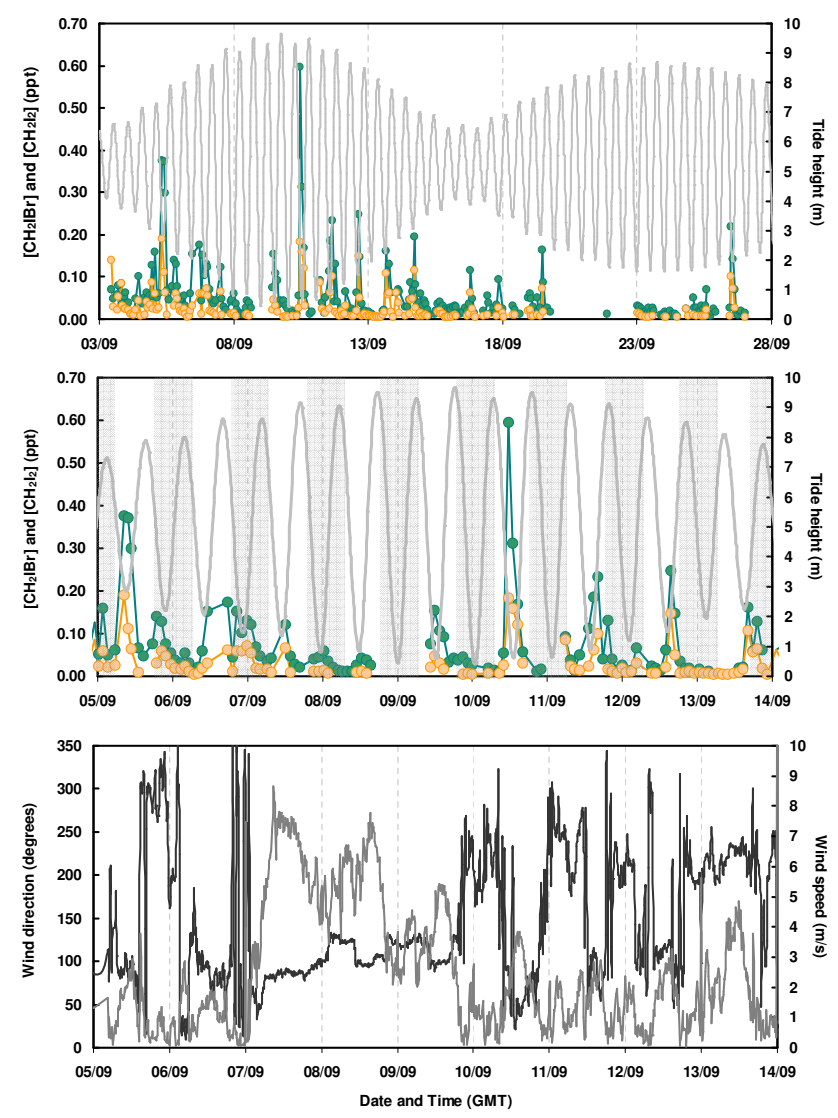

Fig. 2. $\mathrm{CH}_{2} \mathrm{I}_{2}$ (orange) and $\mathrm{CH}_{2} \mathrm{IBr}$ (green) mixing ratios overlaid with tidal height. Grey shaded areas highlight night time measurements $\left(\mathrm{SZA}>90^{\circ}\right)$. Top panel shows data for the whole campaign, middle panel is the period from 5-14 September expanded to illustrate variations in concentrations from low to high tide, and the bottom panel shows wind speed (light grey) and wind direction (dark grey) from 5-14 September.

Figure 2 shows the $\mathrm{CH}_{2} \mathrm{I}_{2}$ and $\mathrm{CH}_{2} \mathrm{IBr}$ concentrations in air during the RHaMBLe campaign overlaid with the tide height. On a number of occasions there was a significant increase in the $\mathrm{CH}_{2} \mathrm{IBr}$ (and to a lesser extent $\mathrm{CH}_{2} \mathrm{I}_{2}$ ) concentration which coincided with low tide (i.e. when the surface footprint around the site contained the most exposed macroalgae). The most significant difference between the low tide and high tide concentrations of these dihalomethanes occurred during the period from the 514 September, which incorporates the spring tides on the 9 and 10 September when the inter-tidal range was greatest, and the highest seaweed biomass was exposed. In addition, the most prolific iodocarbon-producing macroalgae (species from the order Laminariales) typically inhabit only the relatively deeper coastal waters of the lower littoral/sublittoral zones, since they have a substantial root system which requires support (Barnes, 1986; Yonge, 1949). As such, along the coast of Roscoff these plants were only exposed at low tide during the most extreme inter-tidal range. Thus the 
Table 3. Summary of previously published iodocarbon and bromocarbon lifetimes in the sunlit MBL, and the average midday (11 a.m.-2 p.m.) lifetimes for the short-lived dihalomethanes at Roscoff (calculated from the respective measured photolysis rate constants).

\begin{tabular}{|c|c|c|c|}
\hline & $\begin{array}{l}\text { Estimated } \\
\text { lifetime in } \\
\text { the sunlit } \\
\text { MBL }\end{array}$ & Reference & $\begin{array}{l}\text { Average } \\
\text { midday } \\
\text { lifetime } \\
\text { at Roscoff }\end{array}$ \\
\hline $\mathrm{CH}_{2} \mathrm{Br}_{2}$ & $\sim 3-4$ months & $\begin{array}{l}\text { Quack et al. (2007) } \\
\text { Zhang et al. (1997) }\end{array}$ & \\
\hline $\mathrm{CHBr}_{3}$ & $3-5$ weeks & $\begin{array}{l}\text { Bilde et al. (1998) } \\
\text { Quack et al. (2007) } \\
\text { Quack and Wallace } \\
\text { (2003) }\end{array}$ & \\
\hline $\mathrm{CH}_{3} \mathrm{I}$ & $\begin{array}{l}5 \text { days } \\
6 \text { days }\end{array}$ & $\begin{array}{l}\text { Ko and Poulet (2003) } \\
\text { Bell et al. (2002) }\end{array}$ & \\
\hline $\mathrm{C}_{2} \mathrm{H}_{5} \mathrm{I}$ & 4 days & Ko and Poulet (2003) & \\
\hline $\mathrm{CH}_{2} \mathrm{ICl}$ & 0.1 days & Rattigan et al. (1997) & $\sim 4 \mathrm{~h}$ \\
\hline $\mathrm{CH}_{2} \mathrm{IBr}$ & $\sim 1 \mathrm{~h}$ & Mossinger et al. (1998) & $\sim 1 \mathrm{~h}$ \\
\hline $\mathrm{CH}_{2} \mathrm{I}_{2}$ & $2-10 \mathrm{~min}$ & Mossinger et al. (1998) & $\sim 4 \min$ \\
\hline
\end{tabular}

maximum increase in $\mathrm{CH}_{2} \mathrm{IBr}$ and $\mathrm{CH}_{2} \mathrm{I}_{2}$ concentrations during low tide compared to high tide on the 10 September is likely to be a consequence of both the amount and nature of macroalgae exposed.

Despite the lack of statistically significant differences during high and low tide periods overall, concentrations of the longer-lived halocarbons did all appear to exhibit some level of tide-related dependence during the 5-14 September period, for example, it is apparent from Fig. 3 that the $\mathrm{CHBr}_{3}$ (and to a lesser extent $\mathrm{CH}_{2} \mathrm{Br}_{2}$ ) concentration shows some degree of tidal variability.

It should be noted that, in contrast to $\mathrm{CH}_{2} \mathrm{I}_{2}$ and $\mathrm{CH}_{2} \mathrm{IBr}$, $\mathrm{CH}_{2} \mathrm{ICl}$ was present at significantly higher concentrations at high tide relative to low tide during the 5-14 September and throughout the campaign as a whole, suggesting an alternative/additional source of this gas besides biosynthesis from local seaweeds experiencing oxidative stress. $\mathrm{CH}_{2} \mathrm{ICl}$ has strong offshore sources, particularly in shelf seas (Archer et al., 2007; Jones et al., 2009) and given its longer lifetime compared to the other dihalomethanes (see Table 3), the site at Roscoff may potentially have been influenced by regional emissions of $\mathrm{CH}_{2} \mathrm{ICl}$, masking variations in any local macroalgal source. The increase in $\mathrm{CH}_{2} \mathrm{ICl}$ at high tide may also be indicative of a production mechanism within the water rather than from exposed seaweed beds, which is consistent with a photochemical source of $\mathrm{CH}_{2} \mathrm{ICl}$ resulting from photolysis of $\mathrm{CH}_{2} \mathrm{I}_{2}$ in seawater (Jones and Carpenter, 2005, 2006; Martino et al., 2005).
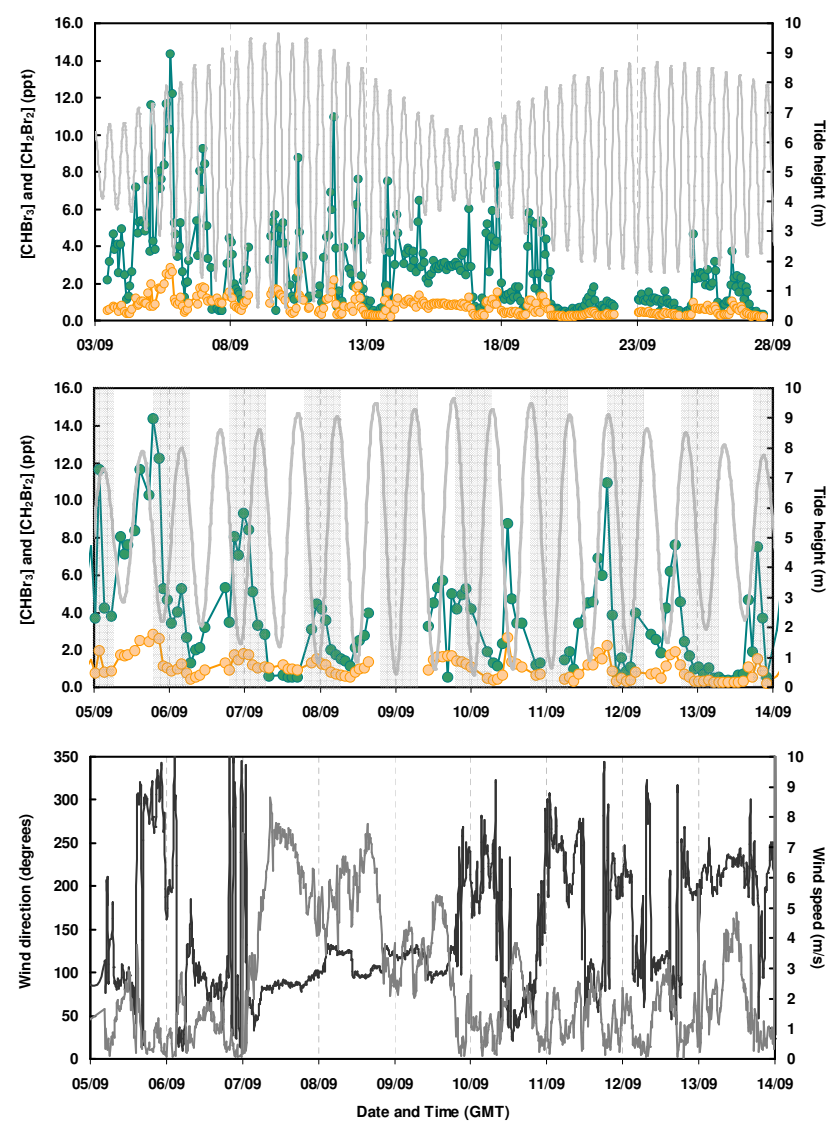

Fig. 3. $\mathrm{CH}_{2} \mathrm{Br}_{2}$ (orange) and $\mathrm{CHBr}_{3}$ (green) mixing ratios overlaid with tidal height. Grey shaded areas highlight night time measurements $\left(\mathrm{SZA}>90^{\circ}\right.$ ). Top panel shows data for the whole campaign, middle panel is the period from 5-14 September expanded to illustrate variations in concentrations from low to high tide and the bottom panel shows wind direction (dark grey) and wind speed (light grey) from 5-14 September.

\subsubsection{Wind speed and direction}

Whilst the tide height and the inter-tidal range play a pivotal role in determining halocarbon concentrations in coastal air, the direction of the air reaching the site is also fundamental, particularly at Roscoff where the distribution of the seaweed species is very non-uniform. During the 5-14 September, when the maximum low tide to high tide ratios of the short-lived $\mathrm{CH}_{2} \mathrm{IBr}$ and $\mathrm{CH}_{2} \mathrm{I}_{2}$ were observed, the site was typically subjected to easterly winds over the channel between Roscoff and Ile de Batz (see Figs. 2 and 4). Consequently, during this period the air reaching the inlet had passed directly over the Laminaria beds. Figures 2 and 3 show that the site consistently experienced easterly winds between the 7 and 10 September (i.e. the air reaching the inlet was passing over the Laminaria), which coincided with moderate tide-related variability in the $\mathrm{CH}_{2} \mathrm{IBr}$ and $\mathrm{CH}_{2} \mathrm{I}_{2}$ concentrations. During the 5-7 and 10-13 September the wind speed was lower (and the wind direction more variable), 

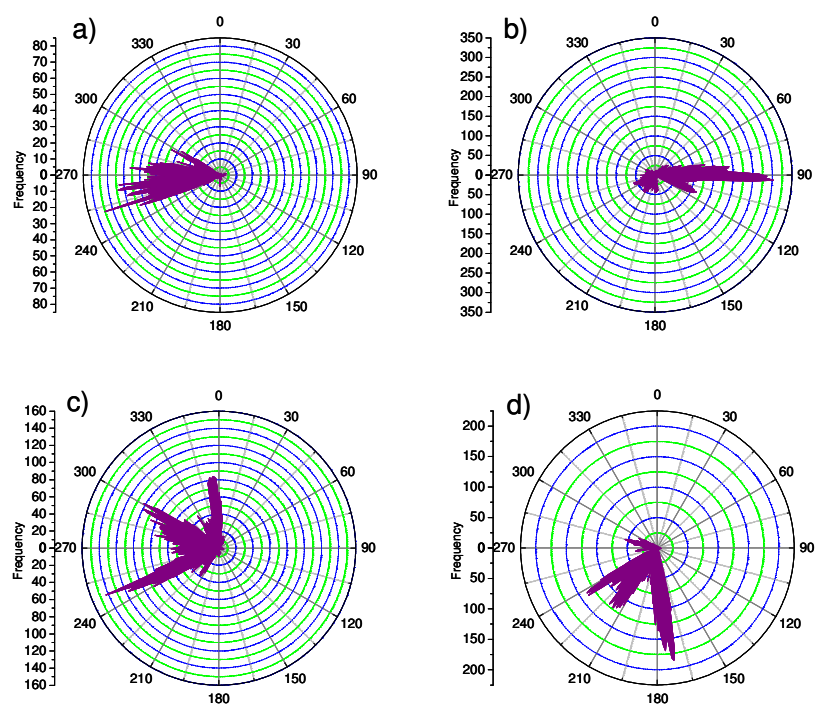

Fig. 4. Wind roses to illustrate the wind direction at the site during four distinct periods; (a) 3-5 September, (b) 5-14 September, (c) 14-21 September and (d) 21-27 September.

and the difference in the $\mathrm{CH}_{2} \mathrm{I}_{2}$ and $\mathrm{CH}_{2} \mathrm{IBr}$ concentrations at high tide compared to low tide became more pronounced, presumably due to less rapid dilution by regional air. It is also evident from Fig. 2 that there was no increase in $\mathrm{CH}_{2} \mathrm{I}_{2}$ or $\mathrm{CH}_{2} \mathrm{IBr}$ coinciding with low tide on the 13 September when the wind speed increased again and the wind direction became predominantly south-westerly. It should be noted that although the wind direction was more variable between the 5-7 and 10-13 September, during periods of maximum dihalomethane concentrations around low tide the wind typically returned to an easterly direction.

There were also statistically significant differences between the mean high tide and low tide concentrations of $\mathrm{CH}_{2} \mathrm{I}_{2}$ and $\mathrm{CH}_{2} \mathrm{IBr}$ from the 14-21 September, when the site received south easterly to north easterly air masses, despite the fact that this period incorporates neap tides with minimum amount of seaweed exposure at low tide. Differences were less significant during the period from the 2127 September when the winds were predominantly southerly across the town rather than passing over the seaweed beds. There was also no significant tide dependent concentration difference apparent in any halocarbon during the 35 September when the site received mainly westerly air masses, however it should be noted that there were only a very limited number of measurements made during this period.

In summary, it appears to be the combination of the largest inter-tidal range, the easterly wind direction and the low wind speeds which gave rise to in the maximum observed $\mathrm{CH}_{2} \mathrm{I}_{2}$ and $\mathrm{CH}_{2} \mathrm{IBr}$ concentrations (and the maximum difference between low tide and high tide concentrations) at Roscoff between the 5-14 September.

\subsubsection{Site topography}

To gain insight into the potential impact of site topography on ambient halocarbon concentrations, the measurements from this work have been compared to observations at another site - Mace Head on the west coast of Ireland (Carpenter et al., 1999, 2003). The coastlines of Roscoff and Mace Head are both north European rocky shores, however at Roscoff the inter-tidal zone is relatively shallow while at Mace Head the shoreline slopes steeply towards the sea. The topography at Mace Head provides apparently optimum conditions for halocarbon emissions, since there is deep water close to the shore suitable for Laminaria to remain submerged at high tide, but as a consequence of the steep shelving shoreline these prolific iodocarbon-producing macroalgae become exposed (and consequently subjected to oxidative stress) at low tide. At Mace Head Laminaria digitata is the dominant species close to the shore, while Laminaria hyperborea is present in the deeper waters further from the coast (Hornsby et al, 2009). Conversely, the very shallow inter-tidal zone at Roscoff means that the waters closest to the shoreline are not deep enough for the Laminaria plants to inhabit, so at Roscoff, although a larger horizontal surface area of seaweed beds becomes exposed at low tide compared to Mace Head, this mainly consists of Fucus species.

Concentrations of the very short-lived dihalomethanes $\mathrm{CH}_{2} \mathrm{IBr}$ and $\mathrm{CH}_{2} \mathrm{I}_{2}$, which appear to be the most sensitive to the local source strength, were present at similar mean concentrations at Mace Head and at Roscoff, however considerably lower maximum concentrations of both gases were observed at Roscoff compared to Mace Head (see Table 1). In incubation studies Pedersen et al. (1996) found that Laminaria digitata produced around 13 times more $\mathrm{CH}_{2} \mathrm{I}_{2}$ than Laminaria saccharina, and so given the abundance of Laminaria digitata at Mace Head, and its exceptionally close proximity to the shoreline, it follows that higher levels of $\mathrm{CH}_{2} \mathrm{I}_{2}$ would be observed here compared to Roscoff. It should be noted that air was sampled at a similar height and distance from the high tide mark at both sites, thus the difference in the maximum levels of the very short-lived iodocarbons at Roscoff compared to Mace Head cannot be explained by differences in the distance between the seaweed beds and the sampling point at the two locations. Thus the higher maximum concentrations of the short-lived dihalomethanes observed at Mace Head are likely due to differences in the seaweed taxonomy and spatial distribution at the two sites, which is a direct consequence of the terrain of the coastline. As such, we conclude that comparison of our measurements of the short-lived dihalomethanes $\mathrm{CH}_{2} \mathrm{IBr}$ and $\mathrm{CH}_{2} \mathrm{I}_{2}$ with those at Mace Head suggests that the concentrations of these gases in MBL air are fundamentally (albeit indirectly) influenced by the topography of the shoreline. 
Table 4. The Spearman's rank coefficients showing the degree of correlation between halocarbons in MBL air at Roscoff. Values in bold are those with a Spearman's rank coefficient of $>0.6$. Superscript ${ }^{\text {a }}$ indicates a correlation which is significant at the $99 \%$ level of confidence.

\begin{tabular}{|c|c|c|c|c|c|c|c|c|}
\hline & $\mathrm{CH}_{2} \mathrm{ICl}$ & $\mathrm{CH}_{2} \mathrm{I}_{2}$ & $\mathrm{CH}_{2} \mathrm{IBr}$ & $\mathrm{C}_{2} \mathrm{H}_{5} \mathrm{I}$ & $1-\mathrm{C}_{3} \mathrm{H}_{7} \mathrm{I}$ & $2-\mathrm{C}_{3} \mathrm{H}_{7} \mathrm{I}$ & $\mathrm{CH}_{2} \mathrm{Br}_{2}$ & $\mathrm{CHBr}_{3}$ \\
\hline $\mathrm{CH}_{2} \mathrm{ICl}$ & & 0.24 & 0.42 & 0.26 & 0.17 & 0.12 & $0.58^{\mathrm{a}}$ & $0.53^{\mathrm{a}}$ \\
\hline $\mathrm{CH}_{2} \mathrm{I}_{2}$ & & & $0.84^{\mathrm{a}}$ & 0.24 & 0.33 & 0.34 & $0.53^{\mathrm{a}}$ & $0.55^{\mathrm{a}}$ \\
\hline $\mathrm{CH}_{2} \mathrm{IBr}$ & & & & 0.32 & 0.36 & 0.25 & $0.72^{\mathrm{a}}$ & $0.72^{\mathrm{a}}$ \\
\hline $\mathrm{C}_{2} \mathrm{H}_{5} \mathrm{I}$ & & & & & $0.83^{\mathrm{a}}$ & $0.54^{\mathrm{a}}$ & 0.32 & 0.21 \\
\hline $1-\mathrm{C}_{3} \mathrm{H}_{7} \mathrm{I}$ & & & & & & $0.61^{\mathrm{a}}$ & 0.15 & 0.08 \\
\hline $2-\mathrm{C}_{3} \mathrm{H}_{7} \mathrm{I}$ & & & & & & & 0.10 & 0.12 \\
\hline $\mathrm{CH}_{2} \mathrm{Br}_{2}$ & & & & & & & & $0.91^{\mathrm{a}}$ \\
\hline $\mathrm{CHBr}_{3}$ & & & & & & & & \\
\hline
\end{tabular}

\subsection{Correlations between halocarbon concentrations in air}

Table 4 shows the Spearman's rank coefficients which indicate the extent of correlation between the MBL concentrations of each of the volatile halocarbons measured. Several iodocarbons were strongly correlated in air during the RHaMBLe campaign (see Fig. 5), which suggests common source(s) for these gases. $\mathrm{CH}_{2} \mathrm{I}_{2}$ and $\mathrm{CH}_{2} \mathrm{IBr}$ were particularly well correlated (Spearman's rank correlation coefficient, $\rho=0.84$, which indicates a correlation significant at $99 \%$ confidence level) as were the iodopropanes $(\rho=0.61$, significant at $99 \%$ confidence level) and $\mathrm{C}_{2} \mathrm{H}_{5} \mathrm{I}$ and $1-\mathrm{C}_{3} \mathrm{H}_{7} \mathrm{I}$ ( $\rho=0.83$, significant at $99 \%$ level $)$.

As shown in Table 4, there were no statistically significant correlations between atmospheric $\mathrm{CH}_{2} \mathrm{ICl}$ and any other iodocarbon. In light of both the contrasting behavior of $\mathrm{CH}_{2} \mathrm{ICl}$ in response to the tide height compared to the other halocarbons (see Sect. 3.1.2), and the absence of any correlation between $\mathrm{CH}_{2} \mathrm{ICl}$ and other organic iodine species in air, we suggest that there are either substantial regional emissions of this gas perturbing local source measurements, or there is a strong local source of $\mathrm{CH}_{2} \mathrm{ICl}$ other than the oxidative stress response of macroalgae in the coastal marine environment.

Strong correlations between brominated organohalogens in both air and seawater have been reported in several other studies (Carpenter and Liss, 2000; Carpenter et al., 2003; Zhou et al., 2008; Carpenter et al., 2009) and are thought to be the result of a common (most likely macroalgal) source of these trace gases. Figure 6 shows that there was a strong correlation between $\mathrm{CH}_{2} \mathrm{Br}_{2}$ and $\mathrm{CHBr}_{3}$ in air at Roscoff $\left(R^{2}=0.85, \rho=0.91\right.$, which corresponds to a correlation that is significant at $99 \%$ confidence level). In addition there was also some degree of correlation (albeit considerably weaker) between $\mathrm{CH}_{2} \mathrm{Br}_{2}$ and $\mathrm{CH}_{2} \mathrm{IBr}\left(R^{2}=0.40, \rho=0.72\right)$ and between $\mathrm{CHBr}_{3}$ and $\mathrm{CH}_{2} \mathrm{IBr}\left(R^{2}=0.32, \rho=0.72\right)$.

Although the concentrations of $\mathrm{CH}_{2} \mathrm{Br}_{2}$ and $\mathrm{CHBr}_{3}$ vary considerably with location, their relative concentrations have been found to remain fairly consistent. The $\mathrm{CH}_{2} \mathrm{Br}_{2}$ mix-
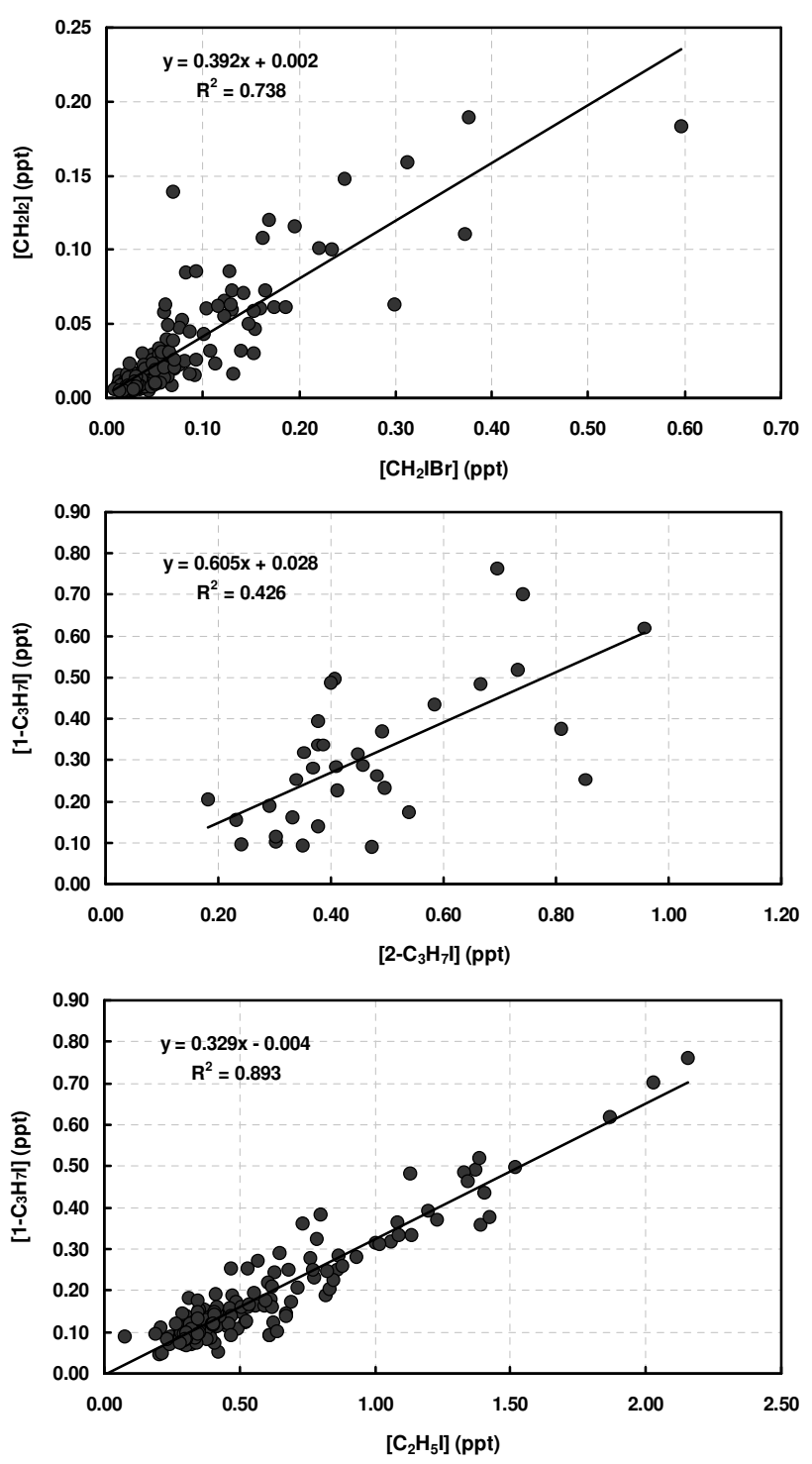

Fig. 5. Correlations between concentrations of iodocarbons in the MBL at Roscoff from 3-27 September 2006 inclusive. 

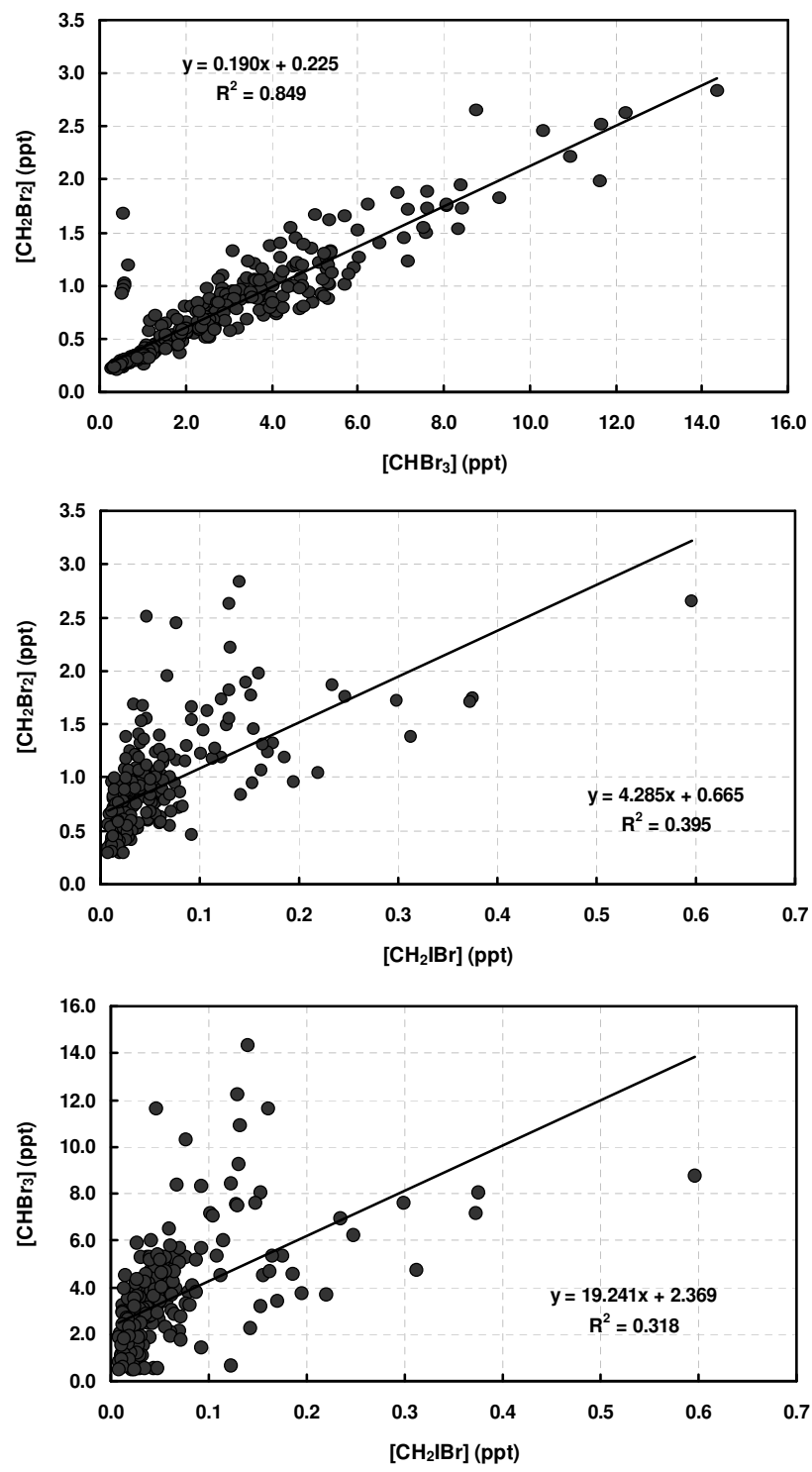

Fig. 6. Correlations between bromocarbons in ambient air at Roscoff from 3-27 September 2006 inclusive.

ing ratio at Roscoff was typically a factor of 0.19 times that of $\mathrm{CHBr}_{3}$ (as shown by the slope of the $\mathrm{CH}_{2} \mathrm{Br}_{2}$ vs $\mathrm{CHBr}_{3}$ plot in Fig. 6). This ratio is in good agreement with the slope of 0.15 derived from measurements of these bromocarbons at Mace Head (Carpenter et al., 2003) and is within the range of $0.08-0.21$ observed in a number of previous studies (Zhou et al., 2008; Carpenter and Liss, 2000; Carpenter et al., 2009 and references therein). Since the bromocarbons have reasonably long atmospheric lifetimes of $\sim 0.29$ years for $\mathrm{CH}_{2} \mathrm{Br}_{2}$ (Zhang et al., 1997) and $\sim 20$ days for $\mathrm{CHBr}_{3}$ (Bilde et al., 1998), the ratio of $\mathrm{CH}_{2} \mathrm{Br}_{2} / \mathrm{CHBr}_{3}$ concentrations measured within a few tens of metres of the source may be considered to directly reflect the ratio of the source strength of these gases (Carpenter et al., 2003). The reasonably consis- tent $\mathrm{CH}_{2} \mathrm{Br}_{2} / \mathrm{CHBr}_{3}$ ratio therefore suggests a direct link between emissions of these bromocarbons, implying a common source(s). A further discussion of $\mathrm{CH}_{2} \mathrm{Br}_{2} / \mathrm{CHBr}_{3}$ ratios in air and in seawater is presented in Carpenter et al. (2009).

\subsection{Comparison with other coastal measurements}

As this study has demonstrated, halocarbon emissions from coastal regions are regulated by a complex combination of many different environmental and biological controlling factors, and consequently significant variability between concentrations of these gases at different sites might be expected.

Comparison with previous coastal studies indicates that the iodocarbon concentrations at Roscoff were typically much lower than those observed further along the coast of Brittany at Lilia (Peters et al., 2005), and were more comparable with the concentrations observed at Mace Head on the west coast of Ireland (Carpenter et al., 1999, 2003) (see Table 1). Both the mean and range of $\mathrm{CH}_{2} \mathrm{ICl}$ mixing ratios are in particularly close agreement with those measured at Mace Head, whilst the other (shorter-lived) dihalomethanes $\mathrm{CH}_{2} \mathrm{IBr}$ and $\mathrm{CH}_{2} \mathrm{I}_{2}$ were present at similar mean concentrations, but considerably lower maximum concentrations, at Roscoff (see Sect. 3.1.4). Conversely, the longer lived monoiodinated $\mathrm{C}_{2} \mathrm{H}_{5} \mathrm{I}$ was more concentrated in air at Roscoff compared to Mace Head, and the iodopropanes (which weren't reported in the Mace Head study) were detected at levels similar to the lower limit concentrations measured at Lilia. The range of $\mathrm{C}_{2} \mathrm{H}_{5} \mathrm{I}, 1-\mathrm{C}_{3} \mathrm{H}_{7} \mathrm{I}, 2-\mathrm{C}_{3} \mathrm{H}_{7} \mathrm{I}$ and $\mathrm{CH}_{2} \mathrm{IBr}$ concentrations observed at Roscoff were also in reasonable agreement with measurements at Dagebüll on the German North Sea coast (Peters et al., 2005), while $\mathrm{CH}_{2} \mathrm{ICl}$ and particularly $\mathrm{CH}_{2} \mathrm{I}_{2}$ were lower at Roscoff. The $\mathrm{CH}_{2} \mathrm{ICl}$ concentrations measured at Roscoff were within a similar range to those observed on the coast of the island of Spitzbergen, Norway (Schall and Heumann, 1993).

The maximum $\mathrm{CH}_{2} \mathrm{Br}_{2}$ and $\mathrm{CHBr}_{3}$ concentrations at Roscoff were below the minimum concentrations observed at Lilia by Peters et al. (2005), and like the iodocarbons, are more comparable with concentrations measured at Mace Head and Dagebüll (see Table 1).

\subsection{Halocarbon seawater concentrations and sea-air fluxes}

During the 11 and 25 September a limited number of seawater samples were analysed for halocarbons, alongside the ambient air measurements. Samples were taken from a range of locations between the measurement site at Roscoff and Ile de Batz, at a range of tide heights. The observed halocarbon concentrations are summarised in Table 5. The seawater concentrations at Roscoff (typically a few pmol $\mathrm{dm}^{-3}$ of most halocarbons and up to several hundred pmol $\mathrm{dm}^{-3}$ $\mathrm{CHBr}_{3}$ ) were comparable with other coastal water measurements of these gases (Klick, 1992; Carpenter and Liss, 2000; 
Table 5. Range of halocarbon concentrations measured in seawater, high tide $(>6.5 \mathrm{~m})$ and low tide $(<4.25 \mathrm{~m})$ average concentrations, mean low tide to high tide ratio and mean sea-air fluxes. $*$ due to lack of ambient air $\mathrm{CH}_{3} \mathrm{I}$ measurements in this work the $\mathrm{CH}_{3} \mathrm{I}$ flux was calculated using a mixing ratio of 0.43 ppt (based on Mace Head measurements from Carpenter et al., 1999).

\begin{tabular}{|c|c|c|c|c|c|}
\hline & $\begin{array}{l}\text { Range of } \\
\text { seawater } \\
\text { concentrations } \\
\left(\mathrm{pmol} \mathrm{dm}^{-3}\right)\end{array}$ & $\begin{array}{l}\text { Mean high tide } \\
\text { concentration } \\
(\text { pmol dm }\end{array}$ & $\begin{array}{l}\text { Mean low tide } \\
\text { concentration } \\
\left(\text { pmol dm }^{-3}\right)\end{array}$ & $\begin{array}{l}\text { Mean low } \\
\text { tide/high } \\
\text { tide ratio }\end{array}$ & $\begin{array}{l}\text { Mean sea-air } \\
\text { flux } \\
\left(\mathrm{nmol} \mathrm{m}{ }^{-2} \mathrm{~d}^{-1}\right)\end{array}$ \\
\hline $\mathrm{CH}_{2} \mathrm{ICl}$ & $2.0-7.8$ & 2.5 & 4.5 & 1.8 & 20.3 \\
\hline $\mathrm{CH}_{2} \mathrm{I}_{2}$ & $0.1-4.5$ & 0.8 & 1.2 & 1.6 & 7.5 \\
\hline $\mathrm{CH}_{2} \mathrm{IBr}$ & $1.9-18.9$ & 2.9 & 7.3 & 2.5 & 28.0 \\
\hline $\mathrm{C}_{2} \mathrm{H}_{5} \mathrm{I}$ & $1.1-3.9$ & 2.0 & 2.8 & 1.4 & 22.4 \\
\hline $2-\mathrm{C}_{3} \mathrm{H}_{7} \mathrm{I}$ & $0.8-4.2$ & 1.5 & 2.7 & 1.8 & 13.1 \\
\hline $\mathrm{CH}_{3} \mathrm{I}$ & $9.0-31.8$ & 12.9 & 18.3 & 1.4 & $31.5^{*}$ \\
\hline $\mathrm{CH}_{2} \mathrm{Br}_{2}$ & $8.3-34.4$ & 11.8 & 22.0 & 1.9 & 18.0 \\
\hline $\mathrm{CHBr}_{3}$ & $142.8-519.4$ & 217.4 & 343.2 & 1.6 & 1800.0 \\
\hline
\end{tabular}

Carpenter et al., 2000). All halocarbons exhibited elevated concentrations in seawater during low tide compared to high tide and, with the exception of $\mathrm{CH}_{3} \mathrm{I}$, the highest concentrations were consistently observed in water directly over kelp beds approximately mid-way between the atmospheric measurement site and the island, a region characterised by the presence of the seaweeds Laminaria digitata, Laminaria saccharina and Laminaria ochroleuca (McFiggans et al. 2009). Conversely, seawater closer to the site and to the southern shore of Ile de Batz contained relatively lower levels of halocarbons.

Figure 7 shows correlations between the seawater concentrations of several bromocarbons and iodocarbons. $\mathrm{CHBr}_{3}$ and $\mathrm{CH}_{2} \mathrm{Br}_{2}$ are exceptionally well correlated, supporting the theory of a common source for these gases. The ratio of $\mathrm{CH}_{2} \mathrm{Br}_{2}$ to $\mathrm{CHBr}_{3}$ in seawater is not dissimilar to the slope of 0.09 determined by Carpenter and Liss (2000) for higher concentrations of these bromocarbons (slope $=0.063$, see Fig. 7). $\mathrm{CH}_{2} \mathrm{I}_{2}$ and $\mathrm{CH}_{2} \mathrm{IBr}$ were less well correlated in seawater than in air $\left(R^{2}=0.68\right.$, and at lower concentrations there was no strong relationship at all), however the correlation observed between these dihalomethanes broadly supports the hypothesis of related emission rates for these gases. Unlike in the gas phase, $\mathrm{CH}_{2} \mathrm{ICl}$ in seawater was found to correlate well with both iodocarbons and bromocarbons, in particular $\mathrm{CH}_{2} \mathrm{IBr}$ $\left(R^{2}=0.87\right)$ and $\mathrm{C}_{2} \mathrm{H}_{5} \mathrm{I}$ (an apparent polynomial relationship with $R^{2}=0.95$ ). The particularly strong correlation between $\mathrm{CH}_{2} \mathrm{ICl}$ and $\mathrm{C}_{2} \mathrm{H}_{5} \mathrm{I}$ in seawater implies that these gases may possess a common source in coastal waters, and incubation studies provide some evidence to support this, since they have demonstrated that while Laminaria digitata appears to be the most prolific producer of $\mathrm{CH}_{2} \mathrm{I}_{2}$ and $\mathrm{CH}_{2} \mathrm{IBr}$, Laminaria saccharina produces the highest concentrations of both $\mathrm{C}_{2} \mathrm{H}_{5} \mathrm{I}$ and $\mathrm{CH}_{2} \mathrm{ICl}$ (Carpenter et al., 2000). As such, despite the lack of correlation between $\mathrm{C}_{2} \mathrm{H}_{5} \mathrm{I}$ and $\mathrm{CH}_{2} \mathrm{ICl}$ within the MBL (which could potentially be explained to some ex- tent by differences in their gas phase photolytic lifetimes, see Table 3), the apparent correlation between $\mathrm{C}_{2} \mathrm{H}_{5} \mathrm{I}$ and $\mathrm{CH}_{2} \mathrm{ICl}$ in seawater, together with evidence from incubation experiments, suggests that these gases may possess a common source in coastal waters.

Sea-air fluxes based on these seawater concentrations and simultaneously measured halocarbon concentrations in air have been calculated using the Nightingale et al. (2000) approximation for the gas transfer coefficient $k\left(\left\{0.222 u^{2}+0.333 u\right\}\left\{S_{C} / 660\right\}^{-1 / 2}\right)$, the dimensionless Henry's law coefficients from Moore et al. (1995) and the Khalil et al. (1999) approximation for the temperature dependent Schmidt numbers. Mean average sea-air fluxes for each halocarbon based on our limited number of seawater measurements are given in Table 5.

\subsection{Contribution to I atom flux}

The rate of atmospheric I atom production from the most photolabile iodocarbons - the dihalomethanes $\mathrm{CH}_{2} \mathrm{I}_{2}$, $\mathrm{CH}_{2} \mathrm{IBr}$ and $\mathrm{CH}_{2} \mathrm{ICl}$ - have been calculated using the simple equation $d[\mathrm{I}] / d t=n J\left(\mathrm{CH}_{2} \mathrm{IX}\right)\left[\mathrm{CH}_{2} \mathrm{IX}\right]$, where $J\left(\mathrm{CH}_{2} \mathrm{IX}\right)$ is the respective dihalomethane photolysis rate constant $\left(\mathrm{s}^{-1}\right)$ and $n$ is the number of $\mathrm{I}$ atoms released (i.e. $n=1$ for $\mathrm{CH}_{2} \mathrm{IBr}$ and $\mathrm{CH}_{2} \mathrm{ICl}$ and $n=2$ for $\mathrm{CH}_{2} \mathrm{I}_{2}$ ). Instantaneous $\mathrm{I}$ atom fluxes have been determined from each individual dihalomethane concentration measurement and the relevant $J\left(\mathrm{CH}_{2} \mathrm{I}_{2}\right), J\left(\mathrm{CH}_{2} \mathrm{IBr}\right)$ and $J\left(\mathrm{CH}_{2} \mathrm{ICl}\right)$ values derived from the on-site spectral radiometer measurements (University of Leicester). The diurnal average I atom fluxes over the whole measurement period from the 3-27 September (incorporating data during both spring and neap tides) are shown in Fig. 8. It is apparent that due to its very short photolytic lifetime (see Table 3) and yield of 2 I atoms per molecule photolysed, $\mathrm{CH}_{2} \mathrm{I}_{2}$ accounts for the majority of $\mathrm{I}$ atom production from dihalomethane photolysis, even though 

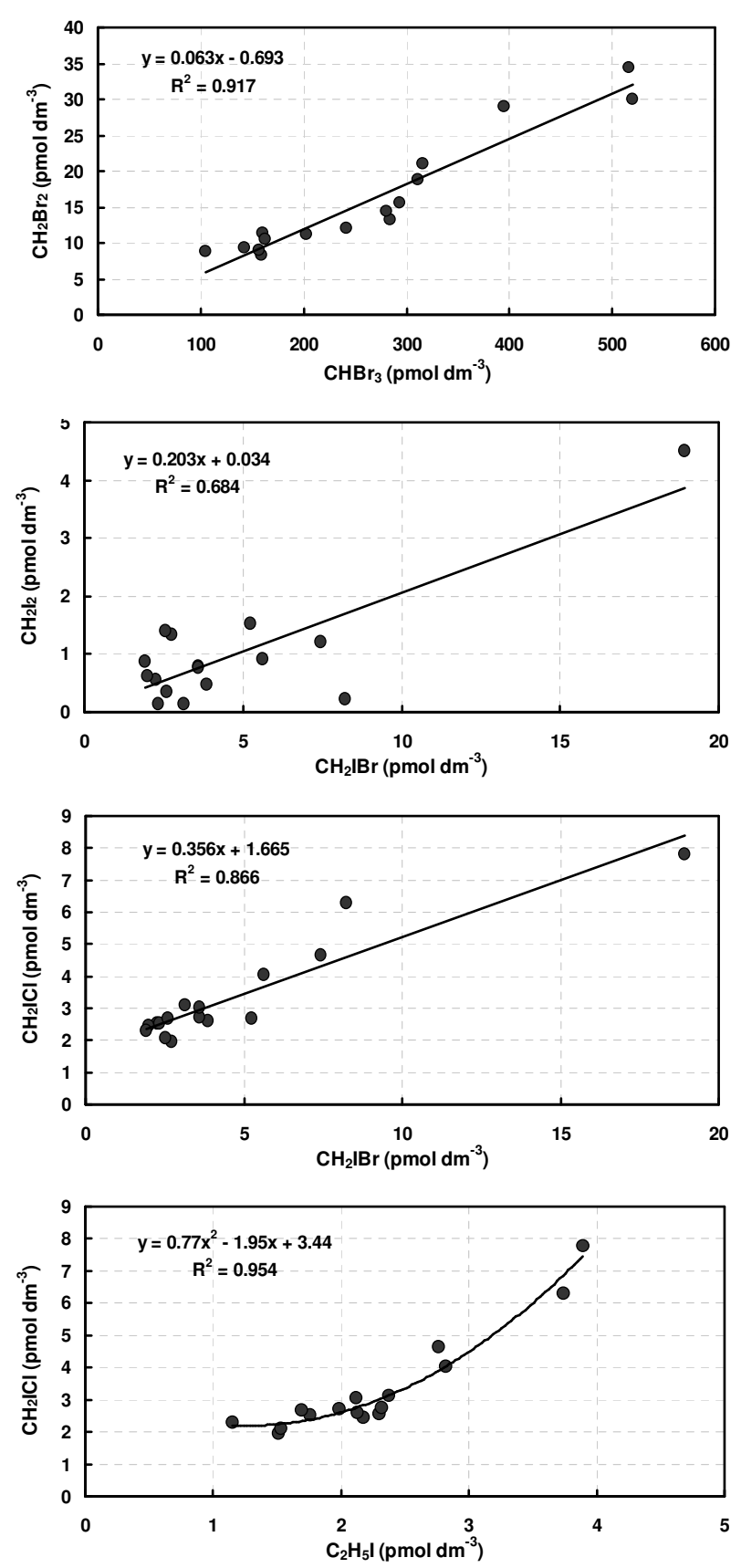

Fig. 7. Correlation plots between halocarbon concentrations in seawater during the 11 and 25 September.

it was present in lower concentrations than $\mathrm{CH}_{2} \mathrm{IBr}$ and $\mathrm{CH}_{2} \mathrm{ICl}$. We calculate a combined average midday (11 a.m.2 p.m. local time) I atom flux from dihalomethanes of around $4.7 \times 10^{3}$ molecules $\mathrm{cm}^{-3} \mathrm{~s}^{-1}$, which is considerably lower than the rate of $I$ atom production from photolysis of $I_{2}$, which we estimate to be roughly $7 \times 10^{7}$ molecules $\mathrm{cm}^{-3} \mathrm{~s}^{-1}$ (based on a mean $\mathrm{I}_{2}$ concentration between 11 a.m. and 2 p.m. of 13 ppt, determined by long path DOAS measurements during the RHaMBLe campaign at Roscoff, Mahajan et al., 2009).

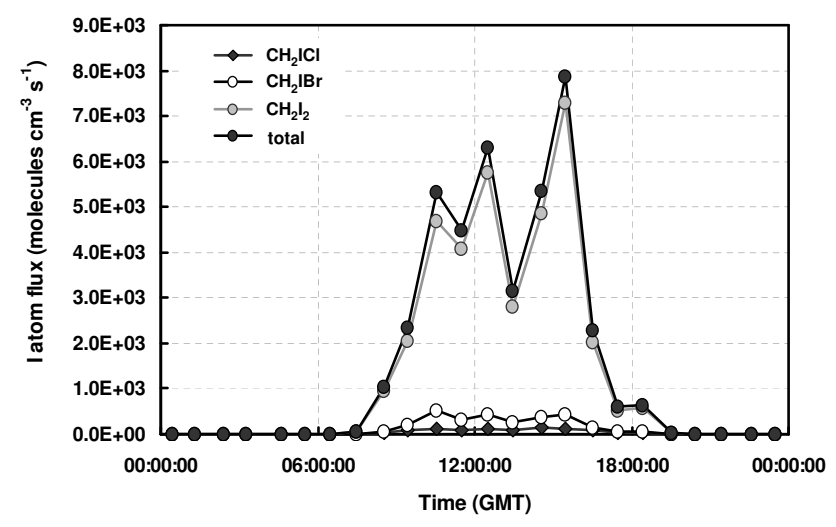

Fig. 8. Diurnal average I atom fluxes from $\mathrm{CH}_{2} \mathrm{ICl}, \mathrm{CH}_{2} \mathrm{IBr}, \mathrm{CH}_{2} \mathrm{I}_{2}$ and the total combined I atom flux from the three dihalomethanes.

Due to the rapid removal of photolabile I atom precursors during the daytime (photolysis lifetimes were $\sim 10 \mathrm{~s}$ and $\sim 4$ min for $\mathrm{I}_{2}$ and $\mathrm{CH}_{2} \mathrm{I}_{2}$ respectively, see Table 3) it is likely that a significant fraction of these trace gases would have been removed before the point of measurement (Mahajan et al., 2009). As such, it may be appropriate to use average night time concentrations in conjunction with midday photolysis rate constants to estimate upper limit I atom fluxes from these species, which would increase the I atom flux from $\mathrm{I}_{2}$ to $\sim 3 \times 10^{8}$ molecules $\mathrm{cm}^{-3} \mathrm{~s}^{-1}$ (assuming an average nocturnal mixing ratio of $60 \mathrm{ppt}$, Mahajan et al., 2009). However, the same approximation cannot be made for the iodocarbons, since this assumes a constant emission rate between day and night, and the maximum observed concentrations of the dihalomethanes typically coincided with daytime low tide (see Fig. 2), with lower concentrations at night, which implies that emissions of these gases exhibit some level of lightdependence. This is consistent with incubation experiments which have demonstrated that the rate of halocarbon production from Laminaria digitata is between 2 and 10 times higher in the light compared to the dark (Carpenter et al., 2000). Therefore, in an attempt to achieve an upper limit estimate of the I atom flux from $\mathrm{CH}_{2} \mathrm{I}_{2}$, we have taken a slightly different approach and approximated the "at source" $\mathrm{CH}_{2} \mathrm{I}_{2}$ concentration, based on the average measured midday concentration, its photolysis rate and an estimated time to reach the GC/MS inlet from the point of emission (assuming that the instrument inlet was $\sim 30 \mathrm{~m}$ from exposed seaweed beds at maximum low tide, and taking the campaign average wind speed of $\sim 3 \mathrm{~m} / \mathrm{s}$ ). This results in a 5\% increase in the $\mathrm{CH}_{2} \mathrm{I}_{2}$ concentration $\left(\mathrm{CH}_{2} \mathrm{IBr}\right.$ and $\mathrm{CH}_{2} \mathrm{ICl}$ concentrations were unchanged within this timescale), and a total I atom flux from the dihalomethanes of $4.9 \times 10^{3}$ molecules $\mathrm{cm}^{-3} \mathrm{~s}^{-1}$, which is still substantially less than the I atom source from $\mathrm{I}_{2}$. 


\section{Conclusions}

It is apparent that biological and physical environmental factors such as the inter-tidal range, wind speed and direction, site topography, seaweed speciation and seaweed distribution greatly influence emissions of reactive halocarbons, and as such caution should be taken in any attempt to scale up coastal measurements from any one site in order to infer global coastal halocarbon emission terms. Our observations at Roscoff show that it is the compounds with the shortest atmospheric lifetimes $\left(\mathrm{CH}_{2} \mathrm{I}_{2}\right.$ and $\left.\mathrm{CH}_{2} \mathrm{IBr}\right)$ that are most strongly effected by variability in the local source strength. Unlike the other gases, we did not observe evidence for a strong local oxidative stress-induced macroalgal source of $\mathrm{CH}_{2} \mathrm{ICl}$, which, together with the absence of any correlation between $\mathrm{CH}_{2} \mathrm{ICl}$ and other iodocarbons in air, implies that there are either substantial regional emissions of this gas dominating over local source measurements, or there is a significant alternative/additional local source of $\mathrm{CH}_{2} \mathrm{ICl}$, for example photochemical production from $\mathrm{CH}_{2} \mathrm{I}_{2}$ in seawater (Jones and Carpenter, 2005; Martino et al., 2005).

Both iodocarbon and bromocarbon concentrations in the MBL at Roscoff were similar to values previously reported at Mace Head in Ireland (Carpenter et al., 1999, 2003), but were considerably lower than the concentrations measured further along the Breton coast at Lilia (Peters et al., 2005).

It is clear that the iodocarbon and $\mathrm{I}_{2}$ measurements made at Roscoff support previous studies which identified $\mathrm{I}_{2}$ as the dominant source of I atoms to the MBL, rather than reactive iodocarbons. It should be noted, however, that given the substantially shorter lifetime of $\mathrm{I}_{2}$ compared to the iodocarbons, the relative contribution from $\mathrm{I}_{2}$ will be greatest closest to the source, and the relative importance of I atom release from the dihalomethanes compared to $I_{2}$ will increase with distance from the point of emission. As such, although directly over seaweed beds I atom production from iodocarbons may be considered insignificant in light of greater production from $\mathrm{I}_{2}$, the iodocarbons do have the potential to increase the spatial extent of I atom release over a broader area compared to a source from $\mathrm{I}_{2}$.

Acknowledgements. The authors thank the NERC SOLAS program (NE/D006554/1) for funding and are grateful to RHaMBLe PI Gordon McFiggans for co-ordinating this campaign. We also thank the staff at The Station Biologique de Roscoff, particularly Philippe Potin and Catherine Leblanc, for their hospitality. KEH acknowledges NERC for her studentship funding.

Edited by: G. McFiggans

\section{References}

Archer, S. D., Goldson, L. E., Liddicoat, M. I., Cummings, D. G., and Nightingale, P. D.: Marked seasonality in the concentrations and sea-to-air flux of volatile iodocarbon compounds in the western English Channel, J. Geophys. Res.-Oceans, 112, C8, C08009, doi:10.1029/2006JC003963, 2007.

Barnes, B.: Coast and shore, a nature guide, The Crowood Press, Marlborough, UK, 1986.

Bell, N., Hsu, L., Jacob, D. J., Schultz, M. G., Blake, D. R., Butler, J. H., King, D. B., Lobert, J. M., and Maier-Reimer, E.: Methyl iodide: Atmospheric budget and use as a tracer of marine convection in global models, J. Geophys. Res., 107, 4340, doi:10.1029/2001JD001151, 2002.

Bilde, M., Wallington, T. J., Ferronato, C., Orlando, J. J., Tyndall, G. S., Estupinan, E., and Haberkorn, S.: Atmospheric chemistry of $\mathrm{CH}_{2} \mathrm{BrCl}, \mathrm{CHBrCl}_{2}, \mathrm{CHBr}_{2} \mathrm{Cl}, \mathrm{CF}_{3} \mathrm{CHBrCl}$, and $\mathrm{CBr}_{2} \mathrm{Cl}_{2}, \mathrm{~J}$. Phys. Chem. A, 102, 1976-1986, 1998.

Bloss, W. J., Lee, J. D., Johnson, G. P., Sommariva, R., Heard, D. E., Saiz-Lopez, A., Plane, J. M. C., McFiggans, G., Coe, H., Flynn, M., Williams, P., Rickard, A. R., and Fleming, Z. L.: Impact of halogen monoxide chemistry upon boundary layer $\mathrm{OH}$ and $\mathrm{HO}_{2}$ concentrations at a coastal site, Geophys. Res. Lett., 32, 6, L06814, doi:10.1029/2004GL022084, 2005.

Butler, J. H., King, D. B., Lobert, J. M., Montzka, S. A., YvonLewis, S. A., Hall, B. D., Warwick, N. J., Mondeel, D. J., Aydin, M., and Elkins, J. W.: Oceanic distributions and emissions of short-lived halocarbons, Global Biogeochem. Cy., 21, 1, GB1023, doi:10.1029/2006GB002732, 2007.

Carpenter, L. J., Sturges, W. T., Penkett, S. A., Liss, P. S., Alicke, B., Hebestreit, K., and Platt, U.: Short-lived alkyl iodides and bromides at Mace Head, Ireland: Links to biogenic sources and halogen oxide production, J. Geophys. Res.-Atmos., 104, 16791689, 1999.

Carpenter, L. J., Malin, G., Liss, P. S., and Kupper, F. C.: Novel biogenic iodine-containing trihalomethanes and other short-lived halocarbons in the coastal East Atlantic, Global Biogeochem. Cy., 14, 4, 1191-1204, 2000.

Carpenter, L. J. and Liss, P. S.: On temperate sources of bromoform and other reactive organic bromine gases, J. Geophys. Res.Atmos., 105, D16, 20539-20547, 2000.

Carpenter, L. J., Liss, P. S., and Penkett, S. A.: Marine organohalogens in the atmosphere over the Atlantic and Southern Oceans, J. Geophys. Res.-Atmos., 108, D9, 4256, doi:10.1029/2002JD002769, 2003.

Carpenter, L. J.: Iodine in the Marine Boundary Layer, Chem. Rev., 103, 12, 4953-4962, 2003.

Carpenter, L. J., Jones, C. E., Dunk, R. M., Hornsby, K. E., and Woeltjen, J.: Air-sea fluxes of biogenic bromine from the tropical and North Atlantic Ocean, Atmos. Chem. Phys., 9, 1805-1816, 2009 , http://www.atmos-chem-phys.net/9/1805/2009/.

Hornsby, K. E., Flynn, M. J., Dorsey, J. R., Gallagher, M. W., Chance, R., Jones, C. E., and Carpenter, L. J.: A Relaxed Eddy Accumulation (REA)-GC/MS system for the determination of halocarbon fluxes, Atmos. Meas. Tech., 2, 437-448, 2009, http://www.atmos-meas-tech.net/2/437/2009/.

Jones, C. E. and Carpenter, L. J.: Solar photolysis of $\mathrm{CH}_{2} \mathrm{I}_{2}$, $\mathrm{CH}_{2} \mathrm{ICI}$, and $\mathrm{CH}_{2} \mathrm{IBr}$ in water, saltwater, and seawater, Environ. Sci. Technol., 39, 16, 6130-6137, doi:10.1021/es050563g, 2005. 
Jones, C. E. and Carpenter, L. J.: Solar photolysis of $\mathrm{CH}_{2} \mathrm{I}_{2}$, $\mathrm{CH}_{2} \mathrm{ICI}$, and $\mathrm{CH}_{2} \mathrm{IBr}$ in water, saltwater, and seawater, Environ. Sci. Technol., 40, 4, 1372, doi:10.1021/es058022e, 2006.

Jones, C. E., Hornsby, K. E., Sommariva, R., Dunk, R. M., von Glasow, R., McFiggans, G., and Carpenter, L. J.: Quantifying the sources and atmospheric impact of marine organic iodine gases, in preparation, 2009.

Khalil, M. A. and Rasmussen, R. A.: Atmospheric chloroform, Atmos. Environ., 33, 7, 1151-1158, 1999.

Klick, S.: Seasonal variations of biogenic and anthropogenic halocarbons in seawater from a coastal site, Limnol. Oceanogr., 37, 7, 1579-1585, 1992.

Ko, M. K. W. and Poulet, G.: The 2002 UNEP/WMO Scientific Assessment of Ozone Depletion, Chapter 2, Very short-lived substances, 2.1-2.57, 2002.

Küpper, F. C., Schweigert, N., Gall, E. A., Legendre, J. M., Vilter, $\mathrm{H}$., and Kloareg, B: Iodine uptake in Laminariales involves extracellular, haloperoxidase-mediated oxidation of iodide, Planta, 207, 2, 163-171, 1998.

Küpper, F. C., Carpenter, L. J., McFiggans, G. B., Palmer, C. J., Waite, T. J., Boneberg, E. M., Woitsch, S., Weiller, M., Abela, R., Grolimund, D., Potin, P., Butler, A., Luther, G. W., Kroneck, P. M. H., Meyer-Klaucke, W. and Feiters, M. C.: Iodide accumulation provides kelp with an inorganic antioxidant impacting atmospheric chemistry, P. Natl. Acad. Sci. USA, 105, 19, 69546958, doi:10.1073/pnas.0709959105, 2008.

Laturnus, F.: Volatile halocarbons released from Arctic macroalgae, Mar. Chem., 55, 359-366, 1996.

Mahajan, A. S., Oetjen, H., Saiz-Lopez, A., Lee, J. D., McFiggans, G. B., and Plane, J. M. C.: Reactive iodine species in a semi-polluted environment, Geophys. Res. Lett., 36, L16803, doi:10.1029/2009GL038018, 2009.

Martino, M., Liss, P. S., and Plane, J. M. C.: The photolysis of dihalomethanes in surface seawater, Environ. Sci. Technol., 39, 18, 7097-7101, doi:10.1021/es048718s, 2005.

McFiggans, G., Coe, H., Burgess, R., Allan, J., Cubison, M., Alfarra, M. R., Saunders, R., Saiz-Lopez, A., Plane, J. M. C., Wevill, D., Carpenter, L., Rickard, A. R., and Monks, P. S.: Direct evidence for coastal iodine particles from Laminaria macroalgae - linkage to emissions of molecular iodine, Atmos. Chem. Phys., 4, 701-713, 2004, http://www.atmos-chem-phys.net/4/701/2004/.

McFiggans, G., Flynn, M., Gallagher, M., Longley, I., Whitehead, J., Furneaux, K., Heard, D. E., Mahajan, A., Oetjen, H., Plane, J. M. C., Whalley, L., Ball, S. M., Hollingsworth, A., Kramer, L., Leigh, R., Monks, P. S., Carpenter, L. J., Dunk, R. M., Hornsby, K. E., Jones, C. E., Lee, J. D., Benton, A., Jones, R. L., Langridge, J., Shillings, A., Potin, P., Leblanc, C., Beams, J., Orr-Ewing, A., and Wada, R.: Reactive Halogens in the Marine Boundary Layer (RHaMBLe): overview of measurements in the Roscoff coastal study, Atmos. Chem. Phys. Discuss., submitted, 2009.

Moore, R. M., Geen, C. E., and Tait, V. K.: Determination of Henry law constants for a suite of naturally-occurring halogenated methanes in seawater, Chemosphere, 30, 6, 1183-1191, 1995.

Moore, R. M. and Groszko, W.: Methyl iodide distribution in the ocean and fluxes to the atmosphere, J. Geophys. Res., 104, 11163-11171, 1999.
Mössinger, J. C., Shallcross, D. E., and Cox, R. A.: UV-VIS absorption cross-sections and atmospheric lifetimes of $\mathrm{CH}_{2} \mathrm{Br}_{2}$, $\mathrm{CH}_{2} \mathrm{I}_{2}$ and $\mathrm{CH}_{2} \mathrm{BrI}$, J. Chem. Soc., Faraday Trans., 94, 13911396, 1998.

Nielsen, J. E. and Douglass, A. R.: Simulation of bromoform's contribution to stratospheric bromine, J. Geophys. Res.-Atmos., 106, D8, 8089-8100, 2001.

Nightingale, P. D., Malin, G., Law, C. S., Watson, A. J., Liss, P. S., Liddicoat, M. I., Boutin, J., and Upstill-Goddard, R. C.: In situ evaluation of air-sea gas exchange parameterizations using novel conservative and volatile tracers, Global Biogeochem. Cy., 14, 1, 373-387, 2000.

Palmer, C. J., Anders, T. L., Carpenter, L. J., Kupper, F. C., and McFiggans, G. B.: Iodine and halocarbon response of Laminaria digitata to oxidative stress and links to atmospheric new particle production, Environ. Chem., 2, 4, 282-290, doi:10.1071/EN05078, 2005.

Pedersen, M., Collen, J., Abrahamsson, K., and Ekdahl, A.: Production of halocarbons from seaweeds: An oxidative stress reaction?, Sci. Mar., 60, 257-263, 1996.

Peters, C., Pechtl, S., Stutz, J., Hebestreit, K., Hönninger, G., Heumann, K. G., Schwarz, A., Winterlik, J., and Platt, U.: Reactive and organic halogen species in three different European coastal environments, Atmos. Chem. Phys., 5, 3357-3375, 2005 , http://www.atmos-chem-phys.net/5/3357/2005/.

Pfeilsticker, K., Sturges, W. T., Bosch, H., Camy-Peyret, C., Chipperfield, M. P., Engel, A., Fitzenberger, R., Muller, M., Payan, S., and Sinnhuber, B. M.: Lower stratospheric organic and inorganic bromine budget for the Arctic winter 1998/99, Geophys. Res. Lett., 27, 20, 3305-3308, 2000.

Pirjola, L., O’Dowd, C. D., Yoon, Y. J., and Sellegri, K.: Modelling iodine particle formation and growth from seaweed in a chamber, Environ. Chem., 2, 4, 271-281, doi:10.1071/EN05075, 2005.

Quack, B. and Wallace, D. W. R.: Air-sea flux of bromoform: Controls, rates, and implications, Global Biogeochem. Cy., 7, 1, 1023, doi:10.1029/2002GB001890, 2003.

Quack, B., Atlas, E., Petrick, G., and Wallace, D. W. R.: Bromoform and dibromomethane above the Mauritanian upwelling: Atmospheric distributions and oceanic emissions, J. Geophys. Res., 112, D09312, doi:10.1029/2006JD007614, 2007.

Rattigan, O. V., Shallcross, D. E., and Cox, R. A.: UV absorption cross-sections and atmospheric photolysis rates of $\mathrm{CF}_{3} \mathrm{I}, \mathrm{CH}_{3} \mathrm{I}$, $\mathrm{C}_{2} \mathrm{H}_{5} \mathrm{I}$ and $\mathrm{CH}_{2} \mathrm{ICl}$, J. Chem. Soc., Faraday Trans., 93, 28392846, 1997.

Read, K. A., Mahajan, A. S., Carpenter, L. J., Evans, M. J., Faria, B. V. E., Heard, D. E., Hopkins, J. R., Lee, J. D., Moller, S. J., Lewis, A. C., Mendes, L., McQuaid, J. B., Oetjen, H., SaizLopez, A., Pilling, M. J., and Plane, J. M. C.: Extensive halogenmediated ozone destruction over the tropical Atlantic Ocean, Nature, 453, 7199, 1232-1235, doi:10.1038/nature07035, 2008.

Saiz-Lopez, A. and Plane, J. M. C.: Novel iodine chemistry in the marine boundary layer, Geophys. Res. Lett., 31, 4, L04112, doi:10.1029/2003GL019215, 2004.

Saiz-Lopez, A., Shillito, J. A., Coe, H., and Plane, J. M. C.: Measurements and modelling of $\mathrm{I}_{2}, \mathrm{IO}, \mathrm{OIO}, \mathrm{BrO}$ and $\mathrm{NO}_{3}$ in the mid-latitude marine boundary layer, Atmos. Chem. Phys., 6, 1513-1528, 2006,

http://www.atmos-chem-phys.net/6/1513/2006/. 
Schall, C. and Heumann, K. G.: GC determination of volatile organoiodine and organobromine compounds in Arctic seawater and air samples, Fresenius J. Anal. Chem., 346, 717-722, 1993.

Sturges, W. T., Oram, D. E., Carpenter, L. J., Penkett, S. A., and Engel, A.: Bromoform as a source of stratospheric bromine, Geophys. Res. Lett., 27, 14, 2081-2084, 2000.

Theiler, R., Cook, J. C., Hager, L. P., and Siuda, J. F.: Halohydrocarbon synthesis by bromoperoxidase, Science, 202, 1094-1096, 1978.

Tokarczyk, R. and Moore, R. M.: Production of volatile organohalogens by phytoplankton cultures, Geophys. Res. Lett., 21, 4, 285-288, 1994.

Wever, R., Tromp, M. G. M., Krenn, B. E., Marjani, A., and Van Tol, M.: Brominating activity of the seaweed Ascophyllum nodosum: Impact on the biosphere, Environ. Sci. Technol., 25, 3, 446-449, 1991.

Wevill, D. J. and Carpenter, L. J.: Automated measurement and calibration of reactive volatile halogenated organic compounds in the atmosphere, The Analyst, 129, 7, 634-638, doi:10.1039/b403550j, 2004.
Wuosmaa, A. M. and Hager, L. P.: Methyl chloride transferase: A carbocation route for biosynthesis of halometabolites, Science, 249, 160-162, 1990.

Vogt, R., Sander, R., von Glasow, R., and Crutzen, P. J.: Iodine chemistry and its role in halogen activation and ozone loss in the marine boundary layer: A model study, J. Atmos. Chem., 32, 3, 375-395, 1999.

Yonge, C. M.: The Sea Shore, The Fontana New Naturalist, Collins, London/Glasgow, UK, 1949.

Zhang, D. Q., Zhong, J. X., and Qiu, L. X.: Kinetics of the reaction of hydroxyl radicals with $\mathrm{CH} 2 \mathrm{Br} 2$ and its implications in the atmosphere, J. Atmos. Chem., 27, 209-215, 1997.

Zhou, Y., Mao, H., Russo, R. S., Blake, D. R., Wingenter, O. W., Haase, K. B., Ambrose, J., Varner, R. K., Talbot, R., and Sive, B. C.: Bromoform and dibromomethane measurements in the seacoast region of New Hampshire 2002-2004, J. Geophys. Res., 113, D08305, doi:10.1029/2007JD009103, 2008. 